\title{
Two New Species of Nematodes (Rhabditida: Diplogasteridae and Rhabditidae) Parasites of Gryllodes laplatae (Orthoptera: Gryllidae) in Argentina
}

\author{
Guillermo R Reboredo+ ${ }^{+}$, Nora B Camino
}

Centro de Estudios Parasitológicos y de Vectores, Calle 2, No. 584, 1900 La Plata, Argentina

Cephalobium magdalensis n. sp. (Rhabditida: Diplogasteridae) found in Magdalena, Buenos Aires, and Cruznema lincolnensis $n$. sp. (Rhabditida: Rhabditidae) found in Lincoln, Buenos Aires, parasitizing the cricket Gryllodes laplatae (Orthoptera: Gryllidae) are described and illustrated. C. magdalensis $n$. sp. is characterized by having the excretory pore between the pseudobulb and the basal bulb and seven pairs of postanal papillae in the male. C. lincolnensis $n$. sp. can be distiguished by having meanly two pairs of preanal papillae, one pair of adanal papillae and six pairs of postanal papillae in the male.

Key words: Cephalobium magdalensis n. sp.- Cruznema lincolnensis n. sp. - Rhabditida Gryllidae taxonomy

While conducting field survey on agricultural pests in Argentina in areas of Lincoln and Magdalena (northwest and east of Buenos Aires Province, respectively) we found adults of Gryllodes laplatae Sauss (Orthoptera: Gryllidae) parasitized by two different Rhabditida species, belonging to the families Diplogasteridae and Rhabditidae. A Diplogasteridae found in Magdalena was Cephalobium magdalensis n. sp. and a Rhabditidae found in Lincoln was Cruznema lincolnensis $\mathrm{n}$. sp.; both species are here described.

\section{MATERIALS AND METHODS}

Adults of $G$. laplatae $(\mathrm{n}=57)$ were hand collected and put in individual vials. According to Poinar's (1975) technique, the insect were placed at $5^{\circ} \mathrm{C}$ for $10 \mathrm{~min}$ and then disected in Petri dishes with distilled water under stereoscope microscope. The nematodes (males and females) were found in the stomodeo intestinal; they were killed in distilled water at $60^{\circ} \mathrm{C}$ for $2 \mathrm{~min}$. Posteriorly they were put in 50\% TAF solution in water for $48 \mathrm{hr}$, finaly we finished the fixed in pure TAF.

Fixed specimens were used for drawings and measurements using a camera lucida microscope, and a micrometer in a Zeiss compound microscope. Measurements are for the holotype male and allotype female and for paratypes the range is in parenthesis.

\footnotetext{
${ }^{+}$Corresponding author. Fax: +54-21-232.327. E-mail: cepave@isis.unlp.edu.ar Received 3 March 1998 Accepted 27 August 1998
}

\author{
RESULTS \\ Orden Rhabditida \\ Family Diplogasteridae \\ Genus Cephalobium Cobb, 1920 \\ Cephalobium magdalensis n. $\mathrm{sp}$.
}

(Fig. 1)

Description - Small sized nematodes, with smooth cuticle. Stoma well developed, with strong and sclerotized walls in the cheilorhabdion; telorhabdion with three teeth: two small and one big and hook-shaped. Oesophagus long and muscular, with a pseudobulb valve and a valveless basal bulb separated by an isthmus. The excretory pore was between the pseudobulb and the basal bulb. Female didelphic, vulva protruding and situated at midbody. Eggs big sized with smooth shell. Male with one testis, spicules parallel, without any sculpture and their length were longer than the body width at level of the anus. Gubernaculum short, wide and triangular. The posterior end of the male presented only postanal papillae, devoid of preanal papillae. There were seven pairs of postanal papillae arranged as follow: one large pair under the anus, three pairs of small papillae, two pairs of little papillae and one large pair at the base of the tail. Tail in both sexes was long and thin.

Male $(\mathrm{n}=17)$ : body length: $2,300 \mu \mathrm{m}(2,125$ $2,550)$; width of head at level of lips papillae: 12.50 $\mu \mathrm{m}$ (11.75-14.10); stoma length: $26.30 \mu \mathrm{m}$ (19.9728.20); stoma width: $8.20 \mu \mathrm{m}$ (7.05-9.40); oesophagus length: $331 \mu \mathrm{m}$ (329-338.40); distance from anterior end to pseudobulb: $227.15 \mu \mathrm{m}$ (216.20-249.10); greatest width of body: $63 \mu \mathrm{m}$ (61.10-65.80); distance from anterior end to excretory pore: $252.03 \mu \mathrm{m}(239.70-289.05)$; distance from anus to tail: $226 \mu \mathrm{m}(223.25-230.30)$; spi- 
cules length: $57.55 \mu \mathrm{m}$ (56.40-58.75); gubernaculum length: $19.45 \mu \mathrm{m}$ (18.80-21.15).

Female $(\mathrm{n}=20)$ : body length: $2,919 \mu \mathrm{m}(2,850-$ 3,025 ); width of head at level of lip papillae: 16.12 $\mu \mathrm{m}(14.10-18.80)$; stoma length: $26.67 \mu \mathrm{m}(24.67-$ 28.20); stoma width: $8.02 \mu \mathrm{m}$ (7.05-9.40); oesophagus length: $353.10 \mu \mathrm{m}(343.10-371.30)$; distance from anterior end to pseudobulb: $266.16 \mu \mathrm{m}$ (253.80-272.60); greatest width of body: 93.72 $\mu \mathrm{m}$ (82.25-105.75); width of body at level of vulva: $103.18 \mu \mathrm{m}$ (96.35-115.15); distance from anterior end to excretory pore: $294.83 \mu \mathrm{m}(284.35-307.85)$; $\mathrm{V}=51 \%$ (50-51.50); length and width of eggs: $73.21 \mu \mathrm{m}(72.55-75.20)$ x $41.15 \mu \mathrm{m}$ (39.95-42.30). Type host: adults of Gryllodes laplatae Sauss (Orthoptera: Gryllidae).
Type locality: horticulture field at Magdalena, Partido de Magdalena, Province of Buenos Aires, Argentina.

Type material: deposited in the helmintological collection of CEPAVE, serie numbered R0017800180 .

\section{DISCUSSION}

The genus Cephalobium was established by Cobb (1920) to accomodate the nematode $C$. microbivorum. Later Artigas (1926), added the species $C$. nitidum to this genus. Oxyuris socialis, a species described by Leidy (1850) was transferred to Leydinemella by Basir (1956). Subsequently in one of the papers presented at Academia Brasileira de Ciências, Travassos and Kloss (1957) trans-

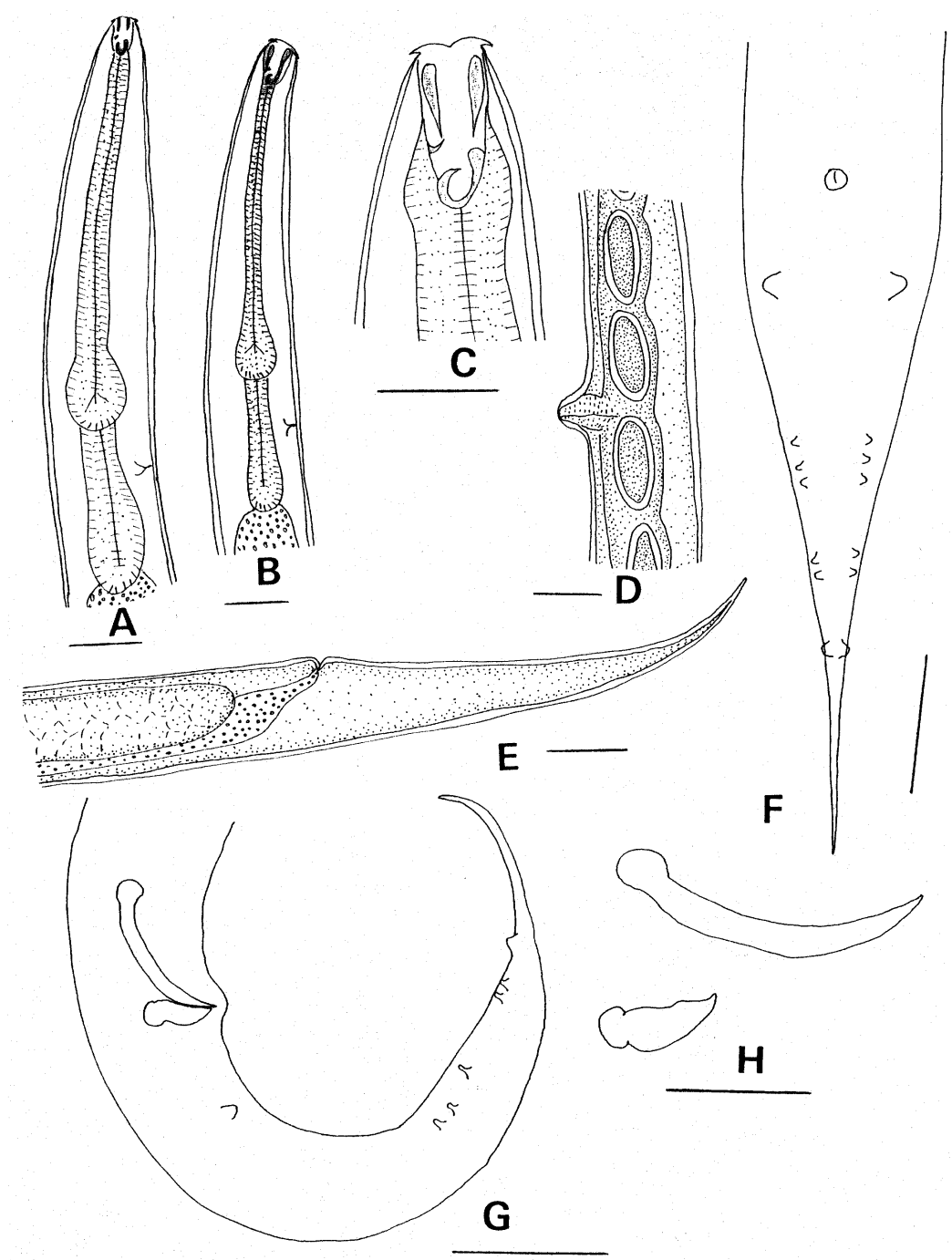

Fig. 1: Cephalobium magdalensis n. sp. A: anterior end of female; B: anterior end of male; C: stoma; D: vagina and uterus with eggs; E: posterior end of female; F: posterior end of male in ventral view; G: posterior end of male in lateral view; H: spicule and gubernaculum. Bars $A, B, D, E, F, G=50 \mathrm{~mm} ; C, H=25 \mathrm{~mm}$. 
ferred $O$. socialis to the genus Cephalobium and considered that the species $C$. microbivorum and C. nitidum indistinguishable from it. Again the two authors in one of their later papers (1960) confirmed the same opinion and $C$. socialis was recognised as one and the only species of the genus.

C. magdalensis sp. $\mathrm{n}$. is the second species of the genus after $C$. socialis (Leidy, 1850) Travassos \& Kloss, 1957, found in crickets (Orthoptera: Gryllidae) in United States and Brazil. Both species have the stoma well developed, long oesophagus, pseudobulb with valve and bulb without valve, the vulva is protruding and the male presents two spicules and have not bursa and preanal papillae.

Our new species can be separated from $C$. socialis by having in the telorhabdion three teeth, two small and one big and hook-shaped. In $C$. socialis the telorhabdion is very sclerotized with wide walls that become larger at the basal end seems to be a little bulb with rudimentary valve; the spicules length in males of $C$. magdalensis $\mathrm{n}$. sp. never exceed one time the body width at level of anus, meanwhile in $C$. socialis this measure is one to one fourth. Another important difference is the position of the excretory pore; in $C$. socialis it can be found between the posterior end of the oesophagus to anterior end of the ovary, but in $C$. magdalensis $\mathrm{n}$. $\mathrm{sp}$. it is between the pseudobulb to the basal bulb. The genital papillae are also differently in number and arragement; in C. magdalensis n. sp. there are seven pairs arranged as follow: one pair under the anus, three pairs of small papillae, two pairs of little papillae and one pair larger and in the base of the tail. In $C$. socialis we find a central and big papilla, two pairs of well developed papillae and near the posterior end, and then a series of minor papillae arranged irregulary.

\section{Orden Rhabditida \\ Family Rhabditidae \\ Genus Cruznema Artigas, 1926 \\ Cruznema lincolnensis $\mathrm{n}$. sp.}

(Fig. 2)

Description - Small nematodes. Body cuticle lightly annulated. Lips papillae well developed, separated by deep furrows and forming a wide cup. Stoma strongly cuticularized, the cheilorhabdion presented one pair of dental plates, the metarhabdion had a single and great dental plate, and the telorhabdion had three dental plates. Oesophagus rhabditoid with pseudobulb avalvated and basal bulb valvated. The excretory pore was at the basal bulb. Vulva posterior, prodelphic. Tail of the female short and conic. Male tail peloderan; spicules long, separated and thin, gubernaculum narrow and nearly half of the spicules length. Bursa peloderan, with nine pairs of genital papillae arranged: two pairs of preanal, one pair adanal and six pairs postanal, which arranged as follow: one pair under the anus, three pairs of papillae and two pairs at the end of the bursa.

Male ( $\mathrm{n}=22)$ : body length: $972 \mu \mathrm{m}(870-1,090)$; width of the head at level of lips papillae: 17.45 $\mu \mathrm{m}$ (16.45-18.80); stoma length: $18.90 \mu \mathrm{m}$ (18.8019.27); stoma width: $4.80 \mu \mathrm{m}$ (4.70-4.95); oesophagus length: $173.33 \mu \mathrm{m}$ (169.20-181.70); distance from the anterior end to pseudobulb: 57.11 $\mu \mathrm{m}$ (51.70-61.10); greatest width of body: 63.66 $\mu \mathrm{m}$ (51.70-77.55); distance from the anterior end to excretory pore: $183.05 \mu \mathrm{m}(178.60-190.35)$; spicules length: $40.40 \mu \mathrm{m}$ (37.60-44.65); gubernaculum length: $20.60 \mu \mathrm{m}$ (17.62-23.50).

Female $(\mathrm{n}=25)$ : body length: $1,435 \mu \mathrm{m}(1,370-$ 1,490); width of head at level of lip papillae: 22.20
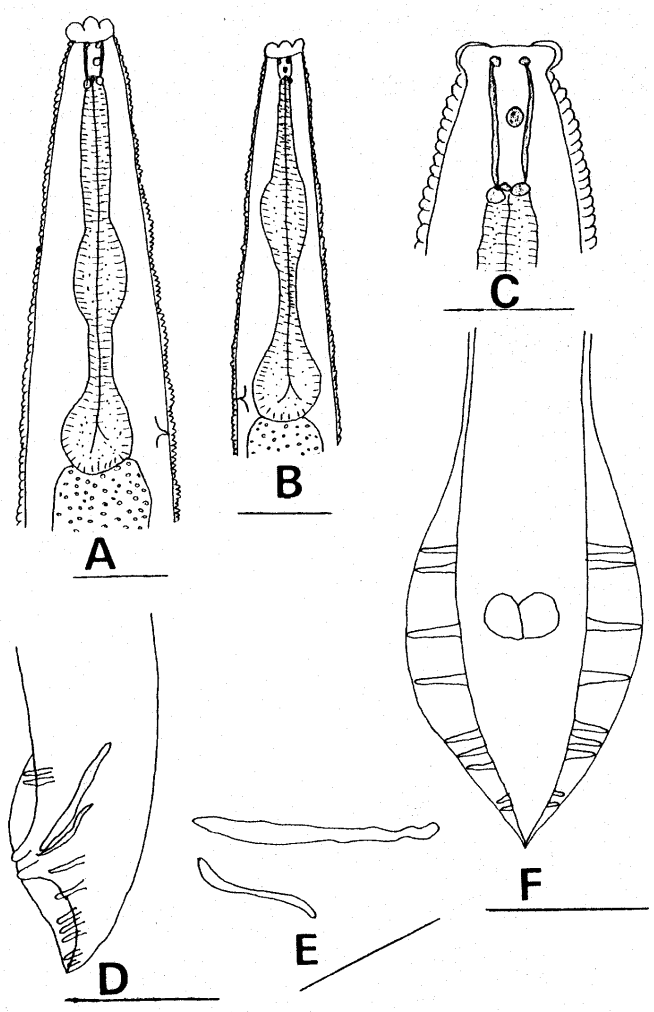

$F$

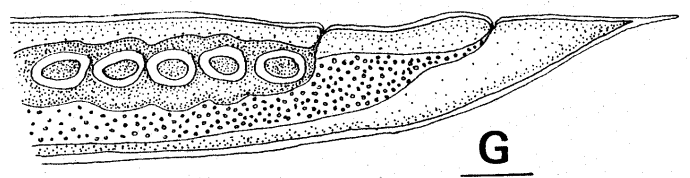

Fig. 2: Cruznema lincolnensis n. sp. A: anterior end of female; B: anterior end of male; C: stoma; D: posterior end of male in lateral view; E: spicule and gubernaculum; F: posterior end of male in ventral view; G: posterior end of female showing vagina and uterus with eggs. Bars A, B, D, E, F, G = $50 \mathrm{~mm}$; C, E $=25 \mathrm{~mm}$. 
$\mu \mathrm{m}$ (21.15-23.50); stoma length: $25.85 \mu \mathrm{m}$ (23.9026.15); stoma width: $4.70 \mu \mathrm{m}$ (4.10-4.95); oesophagus length: $211.42 \mu \mathrm{m}$ (209.15-213.85); distance from the anterior end to pseudobulb: 78.28 $\mu \mathrm{m}$ (75.20-82.25); greatest width of body: 87.62 $\mu \mathrm{m}$ (84.60-91.65); distance from the anterior end to excretory pore: $226.60 \mu \mathrm{m}(225.60-227.95)$; V $=81 \%$ (79-83); length and width of eggs: 49.35 $\mu \mathrm{m}(48.70-50) \times 30.55 \mu \mathrm{m}(30-31.70)$; tail length: $87 \mu \mathrm{m}(84.60-89.30)$.

Type host: adults of Gryllodes laplatae Sauss (Orthoptera: Gryllidae).

Type locality: horticulture field. Escuela de Enseñanza Agropecuaria No. 1, Lincoln, Province of Buenos Aires, Argentina.

Type material: deposited in the helmintological collection of CEPAVE, serie numbered R00181183.

\section{DISCUSSION}

C. lincolnensis $\mathrm{n}$. $\mathrm{sp}$. is similar to C. lambdiensis (Maupas, 1900) Thorne, (1961) and C. brevicaudatum Latheef \& Seshadri, 1972. C. lambdiensis, can be compared to the new species by the presence of prominent lips, papillae surrounding the mouth, and by two pairs of genital preanal papillae. C. lambdiensis differs by having the metarhabdion with three well-formed teeth, the gubernaculum length is $2 / 3$ of the length of the spicules, and by having three pairs of adanal and four postanal genital papillae.

C. brevicaudatum, is similar to $C$. lincolnensis n. sp. by the length of the gubernaculum which is half of the length of the spicules and by having two pairs of preanal genital papillae, but it differs by having in the glottoid apparatus several teeth, the excretory pore is at level of isthmus and by having eigth pairs of postanal genital papillae.

\section{ACKNOWLEDGMENT}

To Ing. Agr. Alejandro E Reboredo, Regente Técnico de la Escuela de Enseñanza Agropecuaria No. 1 de la Ciudad de Lincoln, for technical assistance.

\section{REFERENCES}

Artigas P 1926. Nematoides de invertebrados. Bol biol $S$ Paulo 1: 1-13.

Basir, MA 1956. Oxyuroid parasite of Arthropoda. Zoologica 38, 79 pp.

Cobb, NA 1920. One hundred new nemas (Types species of 100 new genera). Contrib Sci Nematology (IX), 2 p. 1: 217-343.

Latheef MA, Seshadri AR 1972. Cruznema brevicaudatum n. sp. (Nematoda: Rhabditidae) and Indiana coimbatoriensis $\mathrm{n}$. $\mathrm{sp}$. (Nematoda: Pulchrocephalidae) from the mole-cricket, Gryllotalpa africana Beauvois, from India. Canad J Zool 50: 1457-1462.

Leidy J 1850 . Description of some nematoid entozoa infesting insects. Proc Ac Nat Sci Phil 5: 100-102.

Maupas E 1900. Modes et formes de reproduction des nematodes. Arch Zool 8: 463-624.

Poinar Jr GO 1975. Entomogenous Nematodes. A Manual and Host List of Insect-nematode Associations, EJ Brill, Leiden, 317 pp.

Thorne G 1961. Principles of Nematology, McGraw Hill Book Co. Inc., New York, 551 pp.

Travassos L, Kloss GR 1957. Cephalobium socialis (Leidy, 1850) comb. n. An Ac Brasil Ciências 29: 51.

Travassos L, Kloss GR 1960. Compêndio dos nematóides parasitos intestinais de artrópodos. 1 Cephalobiidae, Robertiidae e Rhigonematidae. Arq Mus Nac 5: 237303. 